\title{
Understanding the different types of ALS
}

Steven Karceski, MD

Neurolog $y^{\circledR}$ 2020;94:e880-e883. doi:10.1212/WNL.0000000000009008

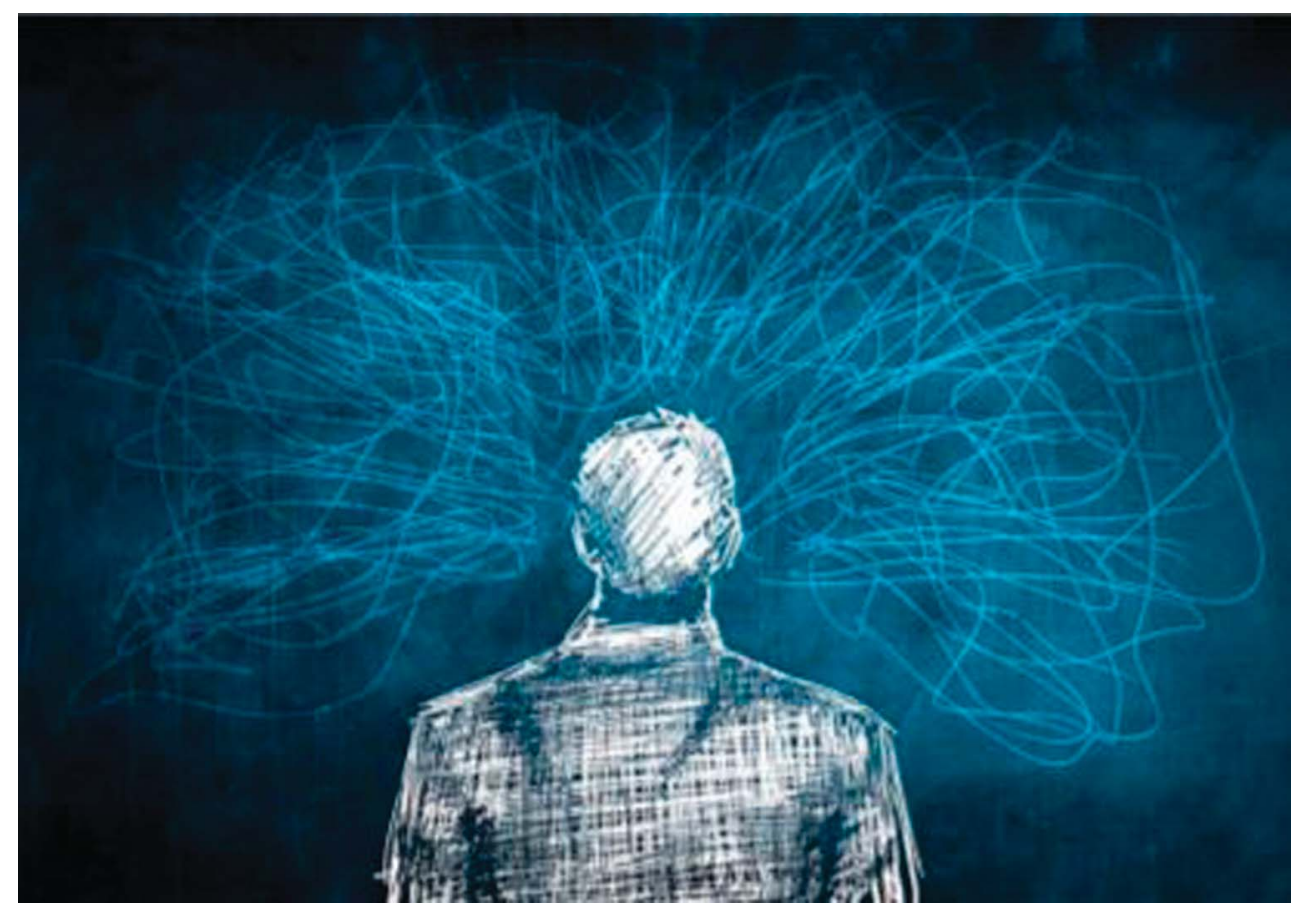

Amyotrophic lateral sclerosis (ALS) occurs in older adults, but it can show itself in many different ways. ALS mostly affects muscle strength. It can affect different muscles in our bodies, and because of this, does not always look the same from one person to another. For instance, some people will have a form of ALS that mostly affects their breathing (or respiratory) muscles. When this happens, they have shortness of breath, even after minor exercise. For others, ALS may affect their throat and mouth muscles first: this results in difficulty swallowing (often called bulbar ALS). With increasing study, scientists have also recognized that may people with ALS not only have muscle weakness, but may also have problems with thinking, or changes in their behavior.

\section{What did the authors study?}

More recently, several studies have shown a connection between ALS and specific genes. Although these genes may not be the cause of ALS, having one or more of these may predispose some people to developing ALS as they get older. In their article, Dr. Chiò et al. studied 2,839 people with ALS (also called Lou Gehrig disease) in order to better understand the different types of ALS (table).

\section{How was the study done?}

Since 1995, in Piedmont, Italy, records have been collected on people who were diagnosed with ALS. Chiò et al. looked at all of these records: in total, there were 2,839 people diagnosed with ALS between January 1, 1995, and December 31, 2015. For many of these people $(2,349)$, records were available over many visits to the doctor, increasing the information and reliability 
Table The patients described by Chiò et al.

\begin{tabular}{lll}
\hline ALS type & Symptoms & No. of people with this type \\
\hline Bulbar & Affects clarity of speech or ability to swallow & 999 \\
\hline Classic & Can affect arms or legs & 835 \\
\hline Predominantly upper motor neuron & Paraplegia or quadriplegia & 240 \\
\hline Flail arm & Shoulder (upper arm) weakness for $>12$ months & 187 \\
\hline Flail leg & Lower leg weakness for $>12$ months & 531 \\
\hline Respiratory & Difficulty breathing & 47
\end{tabular}

Abbreviation: ALS = amyotrophic lateral sclerosis.

of the available information. In this study, the average age of the person with ALS was 67.1 years. ${ }^{1}$

Between 1995 and 2015, 2 changes occurred. First, there was the recognition that ALS was associated with changes in thinking or behavior. In 2007, extensive cognitive testing was added. Because this occurred later in the study, there were a smaller number of people who had this type of testing: 763 . Similarly, genetic testing was started in 2005: of the over 2,800 people in this study, 1,410 had genetic testing.

\section{What did the study show?}

Chiò et al. looked at the different types of ALS, and found the following:

- The swallowing type (bulbar) occurred more in the older group
- The paraparesis or quadriparesis type or the classic type tended to affect younger patients

- Flail arm and the respiratory type occurred more in men

- The abnormal gene (C9orf72 expansions) was related to the bulbar phenotype

- The abnormal SOD1 gene was associated with the flail leg and bulbar types of ALS

Chiò et al. found a strong correlation between the bulbar type of ALS and the development of cognitive problems.

It has long been observed that ALS is a disease that affects us as we get older. Men tend to get ALS more often than women. However, it is not known if there are other, more subtle differences between the different types of ALS. The Chiò et al. study tried to clarify some of these associations. It is through careful study that doctors and scientists can better understand complex diseases like ALS. In this way, improvements in diagnosis and treatment occur. 


\section{About ALS}

Steven Karceski, MD

Neurology ${ }^{\circledR}$ 2020;94:e880-e883. doi:10.1212/WNL.0000000000009008

\section{What is ALS?}

ALS is a progressive neurologic illness that primarily causes worsening muscle weakness. It was first described by the French neurologist Jean-Martin Charcot in 1869. The term ALS comes from the observation of muscle changes in combination with a specific change in the spinal cord. The changes in the spinal cord occur in the location of the nerves to our body's muscles.

\section{Are there different types of ALS?}

ALS can be either sporadic or genetic. The sporadic type is the most common. It accounts for $90 \%$ to $95 \%$ of all cases of ALS. The sporadic type can affect anyone. The genetic or familial type is rarer and accounts for $5 \%-10 \%$ of cases of ALS. The terms familial and genetic mean that this type of ALS is inherited. In families who have genetic ALS, there is an up to $50 \%$ chance that each child will inherit the gene and develop the disease. ${ }^{2}$

\section{Is a diagnosis of ALS common?}

ALS usually affects people between the ages of 40 and 70. Though rare, it is estimated there are more than 16,000 Americans who have the disease at any given time. ALS is often called Lou Gehrig disease. Another notable individual who was diagnosed with ALS was the theoretical physicist and author Stephen Hawking.

\section{What are the symptoms?}

ALS can affect any of the muscles in our bodies, which is why it affects each person differently. In addition, ALS progresses at different rates in different people. For some, it advances quickly. In others, the disease shows a much slower pace. Common symptoms include painless, progressive muscle weakness. Because of the weakness, the first thing a person might notice is tripping more often, or dropping things. Slurred speech, difficulty swallowing, and trouble breathing can occur.

\section{How is ALS diagnosed?}

ALS can be difficult to diagnose. There is not one single test that diagnoses ALS. Instead, the diagnosis is made based on the doctor's observations in combination with a variety of medical tests. Often, a person with these symptoms will have a comprehensive medical workup. Some of the tests performed are as follows:

- EMG: a nerve test

- Blood testing looking for other causes of muscle weakness

- MRI of the brain or spinal cord (or both)

- Spinal tap

- If ALS runs in the family, genetic testing may be performed

There are many reasons to evaluate people carefully who might have ALS. First, a correct diagnosis can help the person (and the family) make plans for care. Second, there are several new treatments for ALS. Making the correct diagnosis is critical to deciding on the best treatment options. 
For more information:

Brain \& Life

brainandlife.org

\section{ALS Association}

alsa.org

\section{ALS Therapy Development Institute} als.net
Les Turner ALS Foundation

lesturnerals.org

\section{References}

1. Chiò A, Moglia C, Canosa A, et al. ALS phenotype is influenced by age, sex, and genetics: a population-based study. Neurology 2020;94:e802-e810.

2. Amyotrophic Lateral Sclerosis Association. Available at: alsa.org. Washington, DC: Amyotrophic Lateral Sclerosis Association. Accessed December 20, 2019. 


\title{
Neurology
}

\author{
Understanding the different types of ALS \\ Steven Karceski \\ Neurology 2020;94;e880-e883 \\ DOI 10.1212/WNL.0000000000009008
}

This information is current as of February 24, 2020

\section{Updated Information \&} Services

References

Permissions \& Licensing

Reprints including high resolution figures, can be found at: http://n.neurology.org/content/94/8/e880.full

This article cites 1 articles, 1 of which you can access for free at: http://n.neurology.org/content/94/8/e880.full\#ref-list-1

Information about reproducing this article in parts (figures,tables) or in its entirety can be found online at:

http://www.neurology.org/about/about_the_journal\#permissions

Information about ordering reprints can be found online:

http://n.neurology.org/subscribers/advertise

Neurology ${ }^{\circledR}$ is the official journal of the American Academy of Neurology. Published continuously since 1951, it is now a weekly with 48 issues per year. Copyright @ 2020 American Academy of Neurology. All rights reserved. Print ISSN: 0028-3878. Online ISSN: 1526-632X.

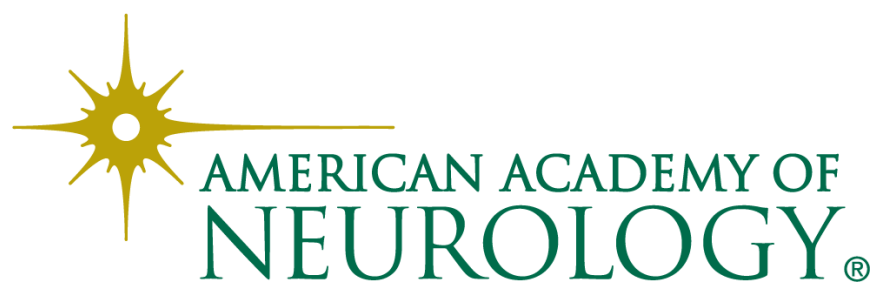

